\title{
PENGARUH FUNGI INDIGENOUS TOLERAN Zn TERHADAP PERTUMBUHAN BIBIT JAGUNG DI MEDIA TAILING STERIL
}

\section{EFFECT OF INDIGENOUS FUNGI TOLERANT Zn ON CORN SEEDLING GROWTH IN STERILE TAILINGS MEDIUM}

\author{
Ratna Santi ${ }^{1}$, Benny Joy ${ }^{2}$, Regina Hindersah ${ }^{2}$ dan Dedi Nusyamsi ${ }^{3}$ \\ ${ }^{1}$ Fakultas Pertanian, Universitas Bangka Belitung, Pangkalpinang, Telp.(0717) 422145 \\ ${ }^{2}$ Fakultas Pertanian, Universitas Padjadjaran, Bandung \\ ${ }^{3}$ BBSDLP, Cimanggu, Bogor \\ Korespondensi : ratnasanti_ubb@yahoo.com
}

Diterima 27 April 2015 /Disetujui 10 Juni 2015

\begin{abstract}
Abstrak
Keberadaan logam $\mathrm{Zn}$ dalam jumlah tertentu di tailing pasca tambang akan berdampak pada rendahnya populasi mikroba tanah dan menghambat pertumbuhan tanaman. Aplikasi pemanfaatan fungi indigenus dari lahan tercemar merupakan salah satu usaha dalam memperbaiki sifat tanah untuk pertumbuhan tanaman. Penelitian ini bertujuan untuk mengetahui pengaruh inokulasi fungi dan toksisitas $\mathrm{Zn}$ terhadap pertumbuhan jagung pada fase VE-V9 di media tailing steril. Fungi diisolasi dari tailing lahan pasca penambangan timah di Sungailiat Bangka. Tiga isolat dari 15 isolat dipilih untuk pengujian pengaruh inokulasi fungi terhadap pertumbuhan jagung. Percobaan menggunakan Rancangan Acak Kelompok(RAK) dua faktor dengan perlakuan jenis fungi dan konsentrasi $\mathrm{Zn}$. Isolat yang digunakan toleran terhadap Zn pada konsentrasi 0-25 ppm dan mampu menghasilkan fitohormon. Hasil percobaan di rumah kaca menunjukkan bahwa inokulasi fungi nyata memperbaiki pertumbuhan jagung, dibandingkan tanpa inokulan. Serapan tertinggi ditunjukkan oleh isolat $\mathrm{R}$ 7J1, namun pertumbuhan jagung terbaik didapatkan dari inokulasi isolat B 2J1.
\end{abstract}

Kata kunci : Fungi, Jagung, Tailing, Zn

\begin{abstract}
The existence of $\mathrm{Zn}$ metal in a certain amount in the post tin mine tailings will result in low soil microbial populations and inhibit plant growth. Application of indigenous fungi utilization on contaminated land is one effort to improve soil properties for plant growth.This study aimed to determine the effect of inoculation of fungi and toxicity of zinc on the growth of corn in the phase of VE-V9 in sterile tailings medium. Fungi were isolated from post tin mining tailings tin lands in Bangka Sungailiat. Three isolates from 15 isolates were selected to test the effect of fungal inoculation on the growth of corn. Experiment used a Randomized Complete Block Design (RCBD) two factors with fungi and $\mathrm{Zn}$ concentration treatments.Tolerant isolates used were at a concentration of 0-25 ppm Zn and capable to produce phytohormones. Result of experiment in greenhouse showed that fungal inoculation substantially improved the growth of maize, compared with no inoculant. The highest uptake was shown by isolates of R 7J1, but the best corn growth inoculation isolates obtained from B $2 J 1$.
\end{abstract}

Key words : Fungi, Maize, Tailings, Zn 


\section{PENDAHULUAN}

Zn termasuk salah satu trace metals yang dalam jumlah tertentu merupakan unsur logam yang dibutuhkan oleh organisme hidup sebagai katalis beberapa enzim (metalloenzim), namun dalam jumlah berlebihan dapat menimbulkan racun (Kabata-Pendias dan Mukherjee, 2007; Sagardoy et al., 2008). Kelebihan Zn pada konsentrasi tertentu pada tanaman dapat menyebabkan klorosis pada daun muda karena defisiensi Fe dan Mg pada tumbuhan (Reichman, 2002; Sagardoy et al, 2010). Kelebihan kandungan $\mathrm{Zn}$ pada manusia menyebabkan disfungsi yang menimbulkan ganguan pada pertumbuhan dan sistem reproduksi (Duruibe et al., 2007).

Penggunaan fungi indigenus dari tanah terkontaminasi dapat sebagai bioagen remediasi yang efektif pada bioremediasi tanah tercemar, berdasarkan kemampuan tumbuh (survival) di lingkungan yang mengandung logam berat tinggi (Iram et al., 2009). Pemanfaatan potensi biologis seperti mikroba indigenus dapat menjadi solusi yang cukup baik dengan kemampuan beradapatasi yang lebih baik pada kondisi lahan tercemar.

Perlu pengujian potensi inokulasi fungi indigenus dan pengaruh $\mathrm{Zn}$ terhadap pertumbuhan bibit tanaman dalam usaha mendapatkan fungi toleran logam yang dapat berasosiasi dengan tanaman. Jagung digunakan sebagai tanaman indikator didasari pada kemampuan tanaman jagung sebagai akumulator logam berat dan kemampuan akar jagung menjadi inang yang bersimbiosis dengan beberapa mikroorganisme (Lasad dan EPA, 2009).

Keberadaan berbagai jenis mikroba di daerah rizosfer akan memperbaiki sistem perakaran tanaman, melalui penyediaan unsur hara dan kemampuan memproduksi fitohormon (Pattern dan Glick, 2002; Yan de et al., 2007). Kuffner et al. (2008), menginformasikan inokulasi Agromyces dan Steptomyces mikrobaindigenus dari rizosfer pada Salix caprea selain resistensi $\mathrm{Zn}$, juga mampu memproduksi IAA (Indole Acetic Acid).

\section{BAHAN DAN METODE}

Percobaan dilakukan di Rumah Kaca Universitas Padjadjaran Jatinangor dari bulan Mei 2014 sampai Juli 2015. Analisis kimia tailing, kompos dan logam Zn dilakukan di Laboratorium Balai Besar Sumber Daya Lahan Pertanian Cimanggu, Bogor.

Percobaan menggunakan Rancangan Acak Kelompok (RAK) faktorial dengan faktor pertama isolat fungi terdiri atas : tanpa isolat, isolat 2J1 dan isolat 7J1. Faktor kedua konsentrasi logam terdiri atas : tanpa Zn (kontrol), 25 ppm Zn dan 50 ppm Zn. Terdapat 9 kombinasi perlakuan dengan tiga ulangan sehingga diperoleh 27 satuan percobaan.

\section{Persiapan media tanam}

Jenis tailing timah yang digunakan pada penelitian ini adalah tailing pasir (sandy tailing) yang diambil secara komposit dari tumpukan tailing di TB tambang 142 Pemali Sungailiat (Kabupaten Bangka Induk). Taling dan kompos yang akan digunakan sebagai media tanam dikering anginkan. Kemudian taling dan kompos sebanyak $250 \mathrm{~g}$ disterilkan dengan autoklaf pada suhu $121^{\circ} \mathrm{C}$ selama 30 menit. Sebagai nutrisi awal untuk tanaman dan mikroba digunakan kompos yang dicampur merata dengan tailing pada saat pembuatan media 
tanam. Media tanam dimasukkan ke dalam pot plastik volume $300 \mathrm{~mL}$ dengan perbandingan tailing dan kompos masingmasing $7: 3$.

\section{Sterilisasi Benih Jagung}

Sterilisasi benih dilakukan dengan cara biji dicuci dengan air mengalir selama 10 menit dan direndam dalam alkohol $70 \%$ selama 30 detik. Alkohol dihilangkan dengan membilas biji menggunakan air steril yang didestilasi sebanyak 3 kali. Kemudian biji direndam dalam larutan $\mathrm{HgCl} \quad 0,05 \%$ selama 5 menit dan dicuci kembali dengan air steril sebanyak tiga kali.

\section{Pembuatan Inokulan}

Pembuatan inokulan cair dengan cara memindahtanamkan biakan murni isolat fungi pada plat agar media PDA. Selanjutnya biakan fungi diinkubasi pada suhu $30{ }^{\circ} \mathrm{C}$ selama 3-7 hari. Biakan murni diletakkan di bawah lampu selama 3 hari untuk menginduksi pertumbuhan spora fungi. Selanjutnya hifa fungi pada plat agar dikoleksi dan disuspensikan ke dalam 10 $\mathrm{ml} \mathrm{NaCl}$ fisiologi. Dengan metode pengenceran diperoleh suspensi fungi dengan kerapatan sel spora $10^{6} \mathrm{CFU} \mathrm{\textrm {mL } ^ { - 1 }}$ menggunakan haemocytometer.

\section{Penanaman dan Inokulasi fungi}

Benih jagung steril dikecambahkan di dalam kertas merang lembab selama dua hari sampai plumula muncul dan tumbuh akar. Benih jagung yang telah berkecambah ditanam pada media tanam sebanyak 2 benih setiap pot. Penjarangan dilakukan setelah benih tumbuh pada umur 5 HST dengan meninggalkan satu tanaman per pot. Inokulasi fungi dilakukan pada saat penanaman, dosis $20 \mathrm{ml}$ per tanaman dengan kepadatan $10^{6}$ spora $\mathrm{mL}^{-1}$.
Teknik inokulasi dilakukan dengan cara menyiramkan inokulum cair ke media tanam (campuran tailing dan kompos) di sekitar perakaran tanaman. Selanjutnya tanaman dipelihara sampai memasuki fase V9 (umur 28 HST) (Subekti et al., 2008). Pemeliharaan dilakukan di Rumah kaca dengan penyiraman 1 kali 1 hari dengan aquades setiap hari untuk menjaga kondisi air tanah pada kapasitas lapang.

\section{Variabel Respons yang Diamati}

Variabel respon pertumbuhan tanaman yang diamati meliputi tinggi tanaman, jumlah daun, berat kering biomassa tanaman. Selanjutnya dilakukan analisis logam $\mathrm{Zn}$ pada biomassa tanaman dan $\mathrm{Zn}$ pada media tanaman tailing diakhir penelitian secara komposit.

\section{Prosedur Analisis Total Zn di Media Tanam dan Biomassa Tanaman}

Metode yang digunakan untuk pengukuran kadar Zn untuk tanah adalah oksidasi contoh tanah dengan $\mathrm{HNO}_{3}$ dan $\mathrm{HClO}_{4}$ dan kandungan diukur dengan atomic absorption spectrophotometer (AAS). Sedangkan Ekstraksi logam berat total tanaman dengan cara pengabuan basah menggunakan campuran $\mathrm{HNO}_{3}$ dan $\mathrm{HClO}_{4}$ dan kandungan diukur dengan atomic absorption spectrophotometer (Jadia dan Fukelar, 2008 dan Sulaeman et al., 2009). Sebanyak 2,5g contoh tanah halus $<0,5 \mathrm{~mm}$ atau contoh tanaman halus $<0,5 \mathrm{~mm}$ dimasukkan ke dalam tabung digest kemudian ditambahkan $5 \mathrm{~mL}$ asam nitrat $\left(\mathrm{HNO}_{3}\right)$ dan dibiarkan satu malam. Setelah 1 malam, dipanaskan pada suhu $100^{\circ} \mathrm{C}$ selama 1 jam 30 menit, didinginkan dan ditambahkan lagi $5 \mathrm{~mL}$ asam nitrat $\left(\mathrm{HNO}_{3}\right)$ dan $1 \mathrm{~mL}$ asam percolat $\mathrm{HClO}_{4}$ atau hydrogen perosida. Larutan tanah dipanaskan hingga $130^{\circ} \mathrm{C}$ selama 1 jam, 
suhu ditingkatkan lagi menjadi $150^{\circ} \mathrm{C}$ selama 2 jam 30 menit hingga uap kuning habis. Setelah uap kuning habis suhu ditingkatkan menjadi $170^{\circ} \mathrm{C}$ selama 1 jam, kemudian suhu ditingkatkan menjadi $200^{\circ} \mathrm{C}$ selama 1 jam sampai terbentuk uap putih. Destruksi selesai dengan terbentuknya endapan putih atau sisa larutan jernih kira - kira sebanyak $1 \mathrm{~mL}$. Ekstrak didinginkan kemudian diencerkan dengan air bebas ion menjadi $25 \mathrm{~mL}$, lalu dikocok hingga homogen dan biarkan semalam. Ekstrak jernih digunakan untuk pengukuran logam berat $\mathrm{Pb}, \mathrm{Zn}$ menggunakan AAS metode nyala untuk tingkat konsentrasi ppm dengan deret standar sebagai pembanding.

\section{Metode Analisis Data}

Data hasil pengamatan untuk respons pertumbuhan tanaman dianalisis dengan menggunakan Sidik Ragam Anova pada taraf $5 \%$ dan bila berbeda nyata dilanjutkan dengan uji Jarak Berganda Duncan.

\section{HASIL DAN PEMBAHASAN}

Tailing yang digunakan untuk penelitian diambil dari lokasi tambang timah aktif PT. Timah TB 142 Sungaliat (Kabupaten Bangka Induk). Tailing mempunyai tingkat kesuburan yang sangat rendah yang dicirikan oleh $\mathrm{pH}$ tanah yang masam $(\mathrm{pH}$ 4.7), C-organik 0.13 (sangat rendah), PBray1 8.25 mg. kg ${ }^{-1}$ (sangat rendah), $\mathrm{N}-$ Total $0.01 \%$ (sangat rendah). Tailing termasuk dalam kelas tekstur pasir (sandy) dengan agihan fraksi pasir mencapai $97 \%$, dan sisanya berupa fraksi debu dan liat. Tingkat kesuburan tailing berdasarkan hasil analis termasuk rendah, maka sebagai sumber hara awal untuk tanaman dan mikroba diberikan kompos sebagai perlakuan dasar. Hasil analisis kimia kompos yang digunakan pada penelitian ini meliputi pH 8.2 (agak alkalis), C-total 9.5\% (sangat tinggi), $\mathrm{N}$-Total $1.03 \%$ (sangat tinggi), $\mathrm{P}_{2} \mathrm{O}_{5}$ Total $0.69 \%$ (sangat rendah), $\mathrm{K}_{2} \mathrm{O}$ Total $1.34 \%$ (sangat rendah), $\mathrm{Zn}$ total 57 mg.kg-1 (sedang).

Hasil pengukuran suhu udara dan kelembaban menggunakan alat hygrometer di Rumah kaca Fakultas Pertanian Unpad Ciparanje suhu pagi $22,10^{\circ} \mathrm{C}$ dan siang $28,53^{\circ} \mathrm{C}$. Kelembaban udara pagi $78,64 \%$ dan siang $45,85 \%$.

\section{Pertumbuhan Tanaman}

Hasil analisis varian menunjukkan bahwa interaksi antara fungi dan $\mathrm{Zn}$ berpengaruh nyata terhadap jumlah daun umur 7 dan 14 HST, namun tidak berpengaruh nyata terhadap jumlah daun 21 dan 28 HST (Tabel 1). Pengaruh inokulasi fungi nyata pada pemberian ketiga taraf $\mathrm{Zn}$ terhadap jumlah daun 14 HST, tetapi tidak berbeda nyata pada 50 $\mathrm{mg} \mathrm{kg} \mathrm{gn}^{-1}$ terhadap jumlah daun 7 HST. Nilai tertinggi didapatkan dari isolat $\mathrm{R} 2 \mathrm{~J} 1$ pada pemberian $25 \mathrm{Zn} \mathrm{mg} \mathrm{kg}{ }^{-1}$ terhadap jumlah daun 7 HST dan $50 \mathrm{mg} \mathrm{kg}^{-1} \mathrm{Zn}$ pada umur 14 HST.

Hasil analisis varian juga menunjukkan bahwa interaksi antara fungi dan $\mathrm{Zn}$ berpengaruh tidak nyata pada tinggi tanaman, namun perlakuan mandiri fungi dan $\mathrm{Zn}$ berpangaruh nyata terhadap tinggi tanaman jagung selama 28 HST (Tabel 2).

Inokulasi fungi dengan nyata dapat memperbaiki pertumbuhan jagung lebih baik dibandingkan dengan perlakuan tanpa inokulan. Perlakuan isolat R $2 J 1$ tidak berbeda nyata terhadap isolat B 7J1 pada tinggi tanaman 21 HST dan jumlah daun 28 HST (Tabel 2 dan 3). 
Pengaruh konsentrasi $\mathrm{Zn}$ berbeda nyata terhadap tinggi tanaman pada umur 7, 21 dan 28 HST, dibandingkan tanpa Zn. Nilai tertinggi terdapat pada perlakuan $50 \mathrm{mg}$ $\mathrm{kg}^{-1} \mathrm{Zn}$, walaupun berbeda tidak nyata dengan $25 \mathrm{mg} \mathrm{kg}^{-1} \mathrm{Zn}$, kecuali pada umur 21 HST terhadap tinggi tanaman (Tabel 2).

Tabel 2. Pengaruh Mandiri Fungi dan Konsentrasi Zn terhadap Tinggi Tanaman Jagung selama 28 HST pada MediaSteril di Rumah kaca

\begin{tabular}{|c|c|c|c|c|}
\hline \multirow{2}{*}{ Perlakuan } & \multicolumn{4}{|c|}{ Tinggi tanaman $(\mathrm{cm})$} \\
\hline & 7 & 14 & 21 & 28 \\
\hline \multicolumn{5}{|l|}{ Fungi } \\
\hline$f_{0}$ (tanpa isolat) & 11,18 a & $18,97 \mathrm{a}$ & $26,25 \mathrm{a}$ & 44,02 a \\
\hline fa (R 2J1) & $12,05 \mathrm{~b}$ & $22,13 \mathrm{~b}$ & $34,74 \mathrm{c}$ & $50,66 \mathrm{~b}$ \\
\hline$f_{b}(B$ 7J1) & $12,81 \mathrm{~b}$ & $21,66 \mathrm{~b}$ & $32,71 \mathrm{~b}$ & $48,45 \mathrm{~b}$ \\
\hline \multicolumn{5}{|l|}{$\mathrm{Zn}$} \\
\hline $\mathrm{k}_{0}\left(0 \mathrm{mg} \mathrm{kg}^{-1}\right)$ & $9,82 \mathrm{a}$ & $20,18 a$ & $29,34 \mathrm{a}$ & 46,21 a \\
\hline $\mathrm{k}_{1}\left(25 \mathrm{mg} \mathrm{kg}^{-1}\right)$ & $13,44 \mathrm{~b}$ & $20,87 a$ & $31,11 b$ & $47,11 a b$ \\
\hline $\mathrm{k}_{2}\left(50 \mathrm{mg} \mathrm{kg}^{-1}\right)$ & $12,77 \mathrm{~b}$ & $21,70 \mathrm{a}$ & $33,25 \mathrm{c}$ & $49,81 \mathrm{~b}$ \\
\hline
\end{tabular}

Keterangan: Angka - angka yang diikuti huruf yang sama pada kolom yang sama tidak berbeda nyata menurut uji Duncan pada taraf $5 \%$

Tabel 3. Pengaruh Mandiri Fungi dan Konsentrasi Zn terhadapjumlah Daun Jagung 21 dan 28 HST pada Media Steril di Rumah kaca

\begin{tabular}{lcc}
\hline \multirow{2}{*}{ Perlakuan } & \multicolumn{2}{c}{ Jumlah Daun $(\mathrm{cm})$} \\
\cline { 2 - 3 } & & 28 \\
\hline Fungi & $3,99 \mathrm{a}$ & $4,44 \mathrm{a}$ \\
$\mathrm{F}_{0}$ (0 isolat) & $4,26 \mathrm{a}$ & $4,88 \mathrm{a}$ \\
$\mathrm{fa}(\mathrm{R}$ 2J1) & $4,22 \mathrm{a}$ & $5,00 \mathrm{~b}$ \\
$\mathrm{f}_{\mathrm{b}}(\mathrm{B} 7 \mathrm{~J} 1)$ & & \\
\hline $\mathrm{Zn}$ & $4,11 \mathrm{a}$ & $4,66 \mathrm{a}$ \\
$\mathrm{k}_{0}\left(0 \mathrm{mg} \mathrm{kg} \mathrm{k}^{-1}\right)$ & $4,18 \mathrm{a}$ & $4,88 \mathrm{a}$ \\
$\mathrm{k}_{1}\left(25 \mathrm{mg} \mathrm{kg}^{-1}\right)$ & $4,18 \mathrm{a}$ & $4,77 \mathrm{a}$ \\
$\mathrm{k}_{2}\left(50 \mathrm{mg} \mathrm{kg}^{-1}\right)$ & & \\
\hline
\end{tabular}

Ket. : Angka - angka yang diikuti huruf yang sama pada kolom yang sama tidak berbeda nyata menurut uji Duncan pada taraf $5 \%$.

Adanya perbedaan respon pertumbuhan tanaman terhadap perlakuan inokulasi dan $\mathrm{Zn}$ berhubungan dengan fase pertumbuhan jagung dan kebutuhan hara termasuk Zn. Pertumbuhan tanaman jagung pada fase 21 dan 28 HST, termasuk dalam fase perkembangan organ vegetatif. Fae V6-V10 berlangsung antara umur 13-35 hari setelah berkecambah. Terjadi penyerapan unsur hara secara optimal disertai dengan perkembangan akar dan pemanjangan batang yang cepat 
(Mc.William et al., 1999 dalam subekti et al., 1999). Hal ini diperkuat dengan hasil penelitian Soudeks et al., (2010), penyerapan hara efektif pada tanaman jagung terjadi pada umur 21-35 HST. Selain itu, inokulasi fungi isolat $\mathrm{R} 2 \mathrm{~J} 1$ diduga

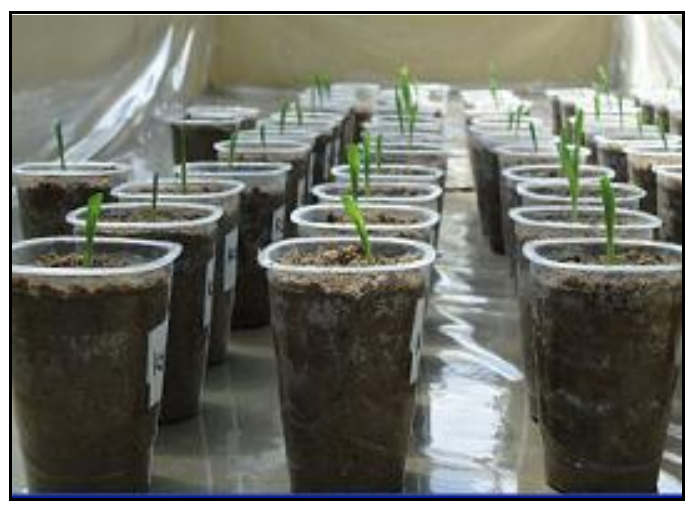

A dapat memberikan ketersediaan hara di media tanam yang lebih baik daripada perlakuan lainnya pada konsentrasi Zn 50 $\mathrm{mg} \mathrm{kg}^{-1}$. Hal ini terlihat dari pertumbuhan tanaman yang lebih baik dibandingkan perlakuan lainnya.

Gambar 1. Pertumbuhan kecambah jagung pada media steril di Rumah kaca pada (A) 3 HST dan (B) 14 HST.

Hasil analisis varian menunjukkan interaksi antara fungi dan konsentrasi $\mathrm{Zn}$ berpengaruh nyata terhadap bobot kering biomassa. Pengaruh inokulasi fungi nyata pada ketiga taraf konsentrasi $\mathrm{Zn}$ terhadap bobot kering biomassa tanaman. Perlakuan inokulasi fungi R 2J1 dan B 7J1 dapat meningkatkan bobot kering biomassa pada pemberian konsentrasi Zn 0, 25 dan $50 \mathrm{mg}$ $\mathrm{kg}^{-1}$, walaupun tidak berbeda nyata antar perlakuan inokulasi (Tabel4).

Tabel 4. Pengaruh Interaksi antara Fungi dan Konsentrasi Zn terhadap Bobot Kering Biomassa Jagung pada Media Steril di Rumah kaca 28 HST

\begin{tabular}{lccc}
\hline \multirow{2}{*}{ Fungi } & \multicolumn{3}{c}{ Berat kering $\left(\mathrm{gtan}^{-1}\right)$} \\
\cline { 2 - 4 } & $0 \mathrm{mg} \mathrm{kg}^{-1} \mathrm{Zn}$ & $25 \mathrm{mg} \mathrm{kg}^{-1} \mathrm{Zn}$ & $50 \mathrm{mg} \mathrm{kg}^{-1} \mathrm{Zn}$ \\
\hline $\mathrm{f}_{0}$ (tanpa isolat) & $7,50 \mathrm{a}$ & $7,35 \mathrm{a}$ & $7,55 \mathrm{a}$ \\
$\mathrm{fa}$ (R 2J1) & $\mathrm{A}$ & $\mathrm{A}$ & $\mathrm{A}$ \\
& $8,64 \mathrm{a}$ & $11,95 \mathrm{~b}$ & $11,10 \mathrm{~b}$ \\
$\mathrm{f}_{\mathrm{b}}$ (B 7J1) & $\mathrm{B}$ & $\mathrm{B}$ & $\mathrm{B}$ \\
& $7,72 \mathrm{a}$ & $12,14 \mathrm{~b}$ & $12,19 \mathrm{~b}$ \\
& $\mathrm{~A}$ & $\mathrm{~B}$ & $\mathrm{~B}$ \\
\hline
\end{tabular}

Keterangan : Angka - angka yang diikuti huruf yang sama pada kolom yang sama tidak berbeda nyata menurut uji Duncan pada taraf $5 \%$. Huruf kecil dan kapital dibaca horizontal dan vertikal.

Inokulasi R 2J1 dan B 7J1 pada Zn 25 dan $50 \mathrm{mg} \mathrm{kg}^{-1}$ lebih meningkatkan bobot biomassa tanaman dibandingkan tanpa $\mathrm{Zn}$. Hal ini diduga karena adanya peningkatan kandungan $\mathrm{Zn}$ di dalam tanah melalui perlakuan konsentrasi $\mathrm{Zn}$ yang awal penelitian hanya $17 \mathrm{mg} \mathrm{kg-1}$ mencapai 50 $\mathrm{mg} \mathrm{kg}{ }^{-1}$. Peningkatan kandungan $\mathrm{Zn}$ akan 
menyebabkan tingginya serapan $\mathrm{Zn}$ oleh tanaman jagung. Konsentrasi $\mathrm{Zn}$ pada batas kecukupan dalam jaringan tanaman akan meningkatkan pertumbuhan dan bobot biomassa tanaman.

Selain itu, inokulasi fungi nyata terhadap bobot kering dibandingkan tanpa inokulan diduga adanya kemampuan dari fungi menghasilkan fitohormon. Auksin, sitokinin dan giberelin merupakan tiga jenis hormone yang berperan dalam proses pemanjangan sel, menstimulasi pertumbuhan tunas, pertumbuhan akar, pemanjangan batang hipokotil, perluasan daun serta metabolisme nutrisi (Baca dan Elmerich, 2003). Penelitian selanjutnya perlu pengujian dan analisis fitohormon pada organ tanaman jagung terutama akar untuk mengetahui kemampuan inokulasi fungi terhadap perkembangan perakaran jagung.

\section{Analisis Logam Zn}

Hasil analisis logam $\mathrm{Zn}$ yang dilakukan pada media tanam dan biomassa tanaman secara komposit menunjukkan adanya keragaman kandungan $\mathrm{Zn}$ pada tiap perlakuan inokulasi fungi (Tabel 5). Serapan tertinggi didapatkan pada perlakuan inokulasi isolat B 7J1 pada konsentasi logam $50 \mathrm{mg} \mathrm{kg}^{-1}$ yaitu $98 \mathrm{mg}$ $\mathrm{kg}^{-1}$ bobot kering. Sedangkan $\mathrm{Zn}$ di media tanam pada perlakuan tersebut adalah $61,7 \mathrm{mg} \mathrm{kg}^{-1}$.

Kandungan $\mathrm{Zn}$ di setiap tanaman percobaan rerata lebih tinggi dari kandungan $\mathrm{Zn}$ pada tanaman jagung umumnya. Terjadi peningkatan kandungan $Z n$ dalam jaringan tanaman, sejalan dengan meningkatnya konsentrasi $\mathrm{Zn}$ pada tiap perlakuan. Hal menunjukkan tanaman jagung mempunyai mekanisme menyerap dan mengakumulasi logam dalam jumlah yang tinggi (Soudek et al., 2010).

Berdasarkan kebutuhan $\mathrm{Zn}$ tanaman, kandungan $\mathrm{Zn}$ dalam jaringan tanaman termasuk tinggi pada perlakuan 25 dan 50 ppm yaitu berada pada kisaran 71-98 ppm $\mathrm{Zn}$. Konsentrasi $\mathrm{Zn}$ pada jagung rata-rata 25-36 mg. kg- ${ }^{1}$ dan tergantung pada genotif dan ekosistem (Kabata-Pendias dan Murherjee, 2007). Kandungan Zn dalam jaringan tanaman jagung tinggi apabila berada pada kisaran diatas 71-81 ppm (Lahudddin, 2007).

Tabel 5. Rerata Total Kandungan Zn dan Biomassa Media tanam Jagung yang Diinokulasi Fungi pada Media Tanam steril di Rumah kaca 28 HST.

\begin{tabular}{|c|c|c|}
\hline \multirow{2}{*}{$\begin{array}{l}\text { Kombinasi } \\
\text { (Fungi + Zn) }\end{array}$} & \multicolumn{2}{|c|}{$\begin{array}{c}\text { Kandungan Zn } \\
\left(\text { mgkg- }^{-1}\right)\end{array}$} \\
\hline & $\begin{array}{l}\text { Bio- } \\
\text { massa }\end{array}$ & $\begin{array}{l}\text { Media } \\
\text { Tanam }\end{array}$ \\
\hline $\begin{array}{l}\mathrm{F}_{\mathrm{o}} \mathrm{k}_{0} \\
\text { (0 isolat }+0 \mathrm{Zn})\end{array}$ & 75 & 32,9 \\
\hline $\begin{array}{l}\mathrm{F}_{\mathrm{o}} \mathrm{k}_{0} \\
\text { (0 isolat }+25 \mathrm{Zn})\end{array}$ & 72 & 49,7 \\
\hline $\begin{array}{l}\mathrm{F}_{\mathrm{o}} \mathrm{k}_{1} \\
(0 \text { isolat }+50 \mathrm{Zn})\end{array}$ & 84 & 48,7 \\
\hline $\mathrm{f}_{\mathrm{a}} \mathrm{k}_{2}(2 \mathrm{~J} 1+0 \mathrm{Zn})$ & 50 & 36,2 \\
\hline $\mathrm{f}_{\mathrm{a}} \mathrm{k}_{1}(2 \mathrm{~J} 1+25 \mathrm{Zn})$ & 96 & 38,8 \\
\hline $\mathrm{f}_{\mathrm{a}} \mathrm{k}_{2}(7 \mathrm{~J} 1+50 \mathrm{Zn})$ & 91 & 59,9 \\
\hline$f_{b} k_{0}(7 J 1+0 Z n)$ & 47 & 52,2 \\
\hline $\mathrm{f}_{\mathrm{b}} \mathrm{k}_{1}(2 \mathrm{~J} 1+25 \mathrm{Zn})$ & 75 & 22,2 \\
\hline $\mathrm{f}_{\mathrm{b}} \mathrm{k}_{2}(7 \mathrm{~J} 1+50 \mathrm{Zn})$ & 98 & 61,7 \\
\hline $\begin{aligned} \text { rangan: } & \text { Analis } \\
& \text { Sumbe } \\
& \text { Ciman }\end{aligned}$ & 3ogor (20 & $\begin{array}{l}a^{a n} \\
\text { ittan) }\end{array}$ \\
\hline
\end{tabular}

Adanya keragaman kandungan $\mathrm{Zn}$ pada perlakuan, diduga berhubungan dengan fase dan kondisi pertumbuhan tanaman dan toleransi fungi terhadap logam. Adanya peningkatan $\mathrm{Zn}$ di media diduga berasal dari perlakuan penambahan konsentrasi $\mathrm{Zn}$ dan masukan $\mathrm{Zn}$ melalui pemberian kompos sebagai nutrisi awal 
tanaman dan mikroba. Selain itu, kandungan maupun ketersediaan Zn dalam tanah bagi tanaman juga yang dipengaruhi kondisi lingkungan tanah dan aktivitas mikroba. Tingginya $\mathrm{Zn}$ yang dapat diserap tanaman diduga berhubungan dengan adanya kemampuan melarutkan mineral $\mathrm{Zn}$ oleh fungi yang diujikan sehingga $\mathrm{Zn}$ tersedia di larutan tanah.

Terjadi penyerapan $\mathrm{Zn}$ oleh mikroba dan tanaman menyebabkan kandungan $\mathrm{Zn}$ di media tanam rendah. Sedangkanpada konsentrasi $50 \mathrm{mg} \mathrm{kg}^{-1}$, diduga terjadi pelarutan $\mathrm{Zn}$ yang dilakukan oleh aktivitas mikroba (fungi) pada sumber $\mathrm{Zn}$ seperti dari kompos dan $\mathrm{Zn}$ terikat pada koloid tanah. Selain bersifat sebagai logam berat, Zn merupakan unsur mikro esensial bagi pertumbuhan tanaman dan metabolisme mikroba (Kabata-Pendias dan Mukherjee, 2007).

Zn dibutuhkan tanaman sebagai kofaktor beberapa enzim (metalloenzim), pembentukan auksin, protein, karbohidrat (Kabata-Pendias dan Mukherjee, 2007); dan meningkatkan jumlah klorofil pada tanaman defesiensi Zn (Cui dan Zhao, 2011). Sedangkan fungi adalah organisme heterotrop, sebagai saprofit sumber energi untuk kerangka karbon berasal dari oksidasi senyawa anorganik. Organisme ini memperoleh energi melalui reaksi reduksioksidasi dari subtrat yang menjadi sunber nutrisinya. Bila dibandingkan dengan perlakuan tanpa inokulan dan tanpa $\mathrm{Zn}$ (foko), diduga $\mathrm{Zn}$ dalam media tanam masih cukup tersedia bagi tanaman yang berasal dari penguraian bahan organik kompos.

\section{SIMPULAN}

Inokulasi fungi dapat memperbaiki pertumbuhan tanaman pada kondisi kelebihan Zn, dibandingkan tanpa inokulan. Pertumbuhan jagung terbaik ditunjukkan oleh inokulasi isola R 2J1. Serapan Zn oleh tanaman jagung setelah 28 HST tertinggi didapatkan pada perlakuan inokulasi fungi B 7J1.

\section{UCAPAN TERIMAKASIH}

Ucapan terimakasih disampaikan
kepada PT. Tambang Timah TBk.
Pangkalpinang Bangka yang telah
membantu, akomodasi dan perjalanan
selama survey lokasi serta pengambilan
bahan penelitian tailing pasir.

\section{DAFTAR PUSTAKA}

Baca, B.E. and C. Elmerich. 2003. Microbial Production of Plant Hormones. In C.Elmerich and W.E. Newton (eds.), Associative and Endophytic Nitrogenfixing Bacteria and Cyanobacterial Associations. Kluwer Akademic Publishers. Netherlands.

Couder, E. 2011. Zn Biogeochemical cycle in highly Zn-contaminated soil-plant system. Universite Catholique Louvain.

Cui, Y. and N. Zhao. 2011. Oxidative stress and change in plant metabolisme of maize (Zea mays. L) growing in contaminated soil with elemental sulfur and toxic effect of Zinc. Plant Soil Environ. Vol. 57 (1):34-39

Duruibe, J.O., Ogwuegbu, M.O.C and Egwurugwu, J.N. 2007. Heavy metal pollution and human biotoxic effects. Leghth Reseach Paper. International PhysicalScience, 2(5): p.112-118

Iram., S., Ahmad, S., Javed., B., Yaqoob, S., Akhtar, K., Kazmi,M.Z and Badar-uz- 
zaman. 2009. Fungal Toleransi Heavy Metals. J Botany, 41(5): p. 2583-2594

Jadia, C.D and M. Fulekar. 2008. Pytoremediation. The aplication of vermecompost to remove $\mathrm{Zn}, \mathrm{Cd}, \mathrm{Cu}$, $\mathrm{Ni}$ and $\mathrm{Pb}$ by sunflower plant. J. Enviromental Engineering and Management. Vol. 7(5):547-558.

Kabata-Pendias, A and Mukherjee, A.B. 2007. Trace Elements from Soil to Human. New york : Springer-Verlag Berlin Heiderlberg.

Kuffner, M., Puschenreiter, M., Wieshammer, G., Gorfer, $M$ and Sessitch, A. 2008. Rhizosphere bacteria affect growth and metal upatake of heavy metal accumulating willows. Plant Soil, 304 : p.35-44

Lahuddin. 2007. Aspek Unsur Mikro dalam Kesuburan Tanah. USU e-Repository. Universitas Sumatera Utara Medan.

Lasad, M.M and EPA, 2009. The Use Plants for Removal of Toxic Metals from Contaminan Soil. America Asosiation for the Advancement of science and Enviromental Ecience and Engineering Fellow. Enviromental Protection Agency (EPA) Published.

Pattern, C.L and Glick, B.R. 2002. Role of Pseudomonas putida indole acetic acid in development of the plant root system. App Enviro Microbial, 63: p.3795-3801

Reichman, S.M. 2002. The Responses of Plants to Metal Toxicity. Focusing on Copper, Manganese and Zinc. Review. Published by Australian Minerals and Energy Enviroment Foundation Published.
Soudek, P., S. Petrova, S, D. Benesova and T. Vanek. 2010. Phytoextraction of toxic metal by sun flower and corn plants. J. Food Agriculture and Enviromental. Vol 8, Issues 3-4:383390.

Subekti, N.A., Safruddin, Efendy, R dan Sunarti, S. 2008. Morfologi Tanaman dan Fase pertumbuhan Jagung. Balai Penelitian Tanaman Serealia. Maros.

Sagardoy, R., Morales, F., Lofez-Milan, A.F., Abadia, A and Abadia, J. 2008. Effects of zinc toxicity on sugar beet (beta vulgaris L.) plant grown in hydroponics. Reseach Paper. J Plant Biology, 11: p.339-350

Sulaeman, Eviati, H. Sastramihardja, S.E. Aprilani dan M. Farida. 2009. Penetapan Unsur Logam Berat Total Cara Pengabuan Basah dengan $\mathrm{HNO}_{3}$ dan $\mathrm{HClO}_{4}$. p. 110-113. In Balai Besar Litbang Sumberdaya Lahan Pertanian (ed.). Analisis Kimia Tanah, Tanman, Air dan Pupuk. Balai penelitian dan Pengembangan Pertanian, Jakarta Selatan

Yan-de, J., Zhen-li, H dan Ziao-e, Y. 2007. Raloe of soil rhizobacteria in phytoremediation of heavy metal contaminated soils. J Zhejiang University Science, 8(3): p.19-25. 